\title{
Influence of polymer and surfactant on the aphrons characteristics: Evaluation of fluid invasion controlling
}

\author{
J. J. F. Cardoso ${ }^{1}$, L. S. Spinelli ${ }^{*}$, V. Monteiro², R. Lomba', E. F. Lucas ${ }^{1}$ \\ ${ }^{1}$ Federal University of Rio de Janeiro, Institute of Macromolecules, Technological Center, Bl. J, Ilha do Fundão, Rio de \\ Janeiro, Brazil \\ ${ }^{2}$ Petrobras Research Center (CENPES), Ilha do Fundão, Q. 9, Rio de Janeiro, Brazil
}

Received 13 January 2010; accepted in revised form 16 March 2010

\begin{abstract}
Aphrons fluids are being studied for application in oil well drilling operation. These fluids consist, basically, of polymer and surfactant, which act as thickening agent and microbubbles producer, respectively. The specific function of aphrons is to act in the filtrate reduction of oil reservoirs presenting low pressure and depleted zones. The aphrons characteristics were evaluated as a function of type and concentration of polymer (xanthan gum-XG and partially hydrolyzed polyacrylamide-PHPA) and surfactant: anionic (Blue Streak ${ }^{\circledR}$, sodium dodecyl sulfate-SDS) and nonionic (polyoxidebased copolymer). Through characterization results (size/size distribution of microbubbles, density and air content) and performance evaluation in the invasion controlling, it was possible to conclude that aphrons fluids prepared with SDS, at an optimal concentration but independent of the polymer type, showed better performance, and such result is related to relatively higher average diameter and broader size distribution of microbubbles, besides the low density and high air content, in the range evaluated in this study.
\end{abstract}

Keywords: industrial applications, surfactant, aphrons, drilling fluids

\section{Introduction}

Drilling of oil wells occurs by using drilling fluids to remove rock fragments as the drilling progresses [1]. Traditionally drilling muds are classified according to the base used to prepare them, which are air, water or oil. Most drilling operations in the world use water-based fluids, due to their low toxicity. Nevertheless, these have some disadvantages that can be overcome by the use of oil-based fluids [2].

Polymers, such as partially hydrolyzed polyacrylamide (PHPA), poly(vinyl acetate-co-maleic anhydride) (PVAMA), xanthan gum (XG) and carboxymethylcellulose (CMC), are applied in the preparation of drilling fluids to act as thickeners, filter loss reducers, clay swelling inhibitors, drag reduction agents, lubricants and dispersants [3-5].
Technology of aphrons-based drilling fluids (structured air microbubbles) was developed in the end of nineteen's. The potential of aphrons as components of drilling fluids rests in their ability to reduce the invasion of the fluid in the rock and to minimize the damages to the formation, due to their high power to seal off depleted zones [6].

According to Sebba, aphrons are colloidal dispersions containing microbubbles of $10-100 \mu \mathrm{m}$ in diameter, whose cores can be composed of a gas, liquid or emulsion encapsulated by various layers of surfactants. The term colloidal is related to the small size of bubbles, despite the dimensions are not in fact at colloids range $(1 \mathrm{~nm}-1 \mu \mathrm{m})[7,8]$.

The encapsulating film protects the aphrons, from a thick film that presents as one a bilayer: the innermost layer contains surfactants whose hydrophobic 
groups are inside the core and hydrophilic groups that are outside it. The external layer (protective layer) has surfactants whose hydrophobic and hydrophilic groups are arranged in the opposite order [8].

Aphrons and regulars foams are instable thermodynamically and, therefore, coalesce as a function of time. The principle of aphrons stability is based mainly on their structure (that is composed by multiples layers of surfactants around of the core), moreover electrostatic interactions or steric repulsions, when using ionic or nonionic surfactants, respectively [7]. The main characteristics of aphrons are also related to structure, such as: large interfacial area in relation to volume, due to the small size of bubbles, and high stability. Usually aphrons are characterized by size and size distribution of microbubbles using microscopy techniques and image analysis, besides others that evaluate their structure by layers thickness and number and microbubbles aggregation [9-11].

The acting mechanism of aphrons fluids during well drilling has been proposed in the literature; when aphrons penetrate the depleted zone, the difference between internal and external pressure causes them to expand, favoring the aggregation of bubbles which results in a micro-environment of bubbles that seal off the depleted formation. This generates enough energy to prevent the invasion of fluids, or filtrate, into the depleted zone. Moreover, there is no formation of filter cake, which reduces the possibility of drilling equipment gets stuck in the well and also mitigates corrosion problems [12].

In spite of the mechanism of aphrons has been ascribed in the literature, there is not enough information about the influence of fluid composition on the microbubbles structure. In a previous work we have presented results about synthetic-based aphrons [13]. This work aims to evaluate the influence of type and concentration of polymer and surfactant on water-based aphrons production and their characteristics of microbubbles size, microbubbles size distribution, density and air content, beyond evaluating their performance as invasion controlling as drilling fluids.

\section{Experimental section 2.1. Materials}

It was used two types of polymers: xanthan gum of molar mass of 2.0 $10^{6}$, Kelco Oil Field Group (Houston, USA), and partially hydrolyzed polyacrylamide (PHPA) of molar mass in the range of 1.0 to $1.2 \cdot 10^{7}$ and hydrolysis degree of $25 \%$, SNF Floerger (Andrézieux, France). The surfactants used were Blue Streak ${ }^{\circledR}$ (commercial) and sodium dodecyl sulfate (SDS) from Vetec Fine Chemical (Rio de Janeiro, Brazil), and the monofunctional branched copolymer of poly(ethylene oxide-bpropylene oxide) (PEO-PPO), named L10, from Dow Chemical (São Paulo, Brazil). Magnesium oxide was used as $\mathrm{pH}$ controller and glutaraldehyde, supplied by Poland Chemical (Rio de Janeiro, Brazil), as biocide.

\subsection{Preparation of aphrons fluids}

Aphrons were prepared in two stages. The first one corresponds to the production of base drilling fluid, with a simple formulation, which contains distillated and deionized water, polymer, magnesium oxide and biocide. This formulation was prepared in a mixer (Hamilton Beach Brands, Washington, USA). The second stage is constituted of the incorporation of the microbubbles in the fresh prepared base fluid by mixing surfactant, stirring in the same mixer and using a filter press (Fann Instrument Company, Houston, USA), without filtering element, under $1.38 \mathrm{MPa}$ (200 psi) of differential pressure [14].

These two thickener polymers (XG and PHPA) were used at $11.4 \mathrm{~kg} / \mathrm{m}^{3}$ (the concentration normally used in drilling fluids of petroleum and gas industry), 5.7 and $22.8 \mathrm{~kg} / \mathrm{m}^{3}$, which correspond to the half and the double of the reference concentration, respectively [15]. The surfactants concentrations were 2.0, 4.0 and $20.0 \mathrm{~kg} / \mathrm{m}^{3}$ for Blue Streak ${ }^{\circledR}$ and L10, and 4.0, 8.0 and $20.0 \mathrm{~kg} / \mathrm{m}^{3}$ for SDS. Such concentration values were depending on the respective critical micellar concentrations (CMC). The magnesium oxide and glutaraldehyde concentrations were kept constant at $2.0 \mathrm{~kg} / \mathrm{m}^{3}$ each. 


\subsection{Fluids characterization}

The aphrons fluids were characterized in terms of:

- Size and number of microbubbles, by analyses of images using an optical microscope (Olympus SZH10, Center Valley, USA) with the program Size Meter 1.1;

- Density, by conventional method that uses the ratio between mass and total volume occupied by the fluid;

- Air content, using a compressibility test that is related to the compressed volume of the aphrons fluid, taking in account the air volume that suffers compression, when applying the same pressure in both cases.

- Viscosity, using the rheometer AR 2000 (TA Instruments, New Castle, USA), with parallel plates, at room temperature.

\subsection{Evaluation of the performance as a filtrate controller}

The performance test was carried out using a procedure adapted from Petrobras N-2607 standard. First, a ceramic filter disk (Fann Instrument Company, Houston, USA) with pore diameter of $10 \mu \mathrm{m}$ was saturated in water to remove the air from the pores. Then, the fluid was passed through the filter cell containing the disk under a differential pressure of $0.69 \mathrm{MPa}(100 \mathrm{psi})$. The mass of fluid expelled from the filter press per unit of time was determined. This procedure was applied to the aphrons and their respective base fluids. These results allowed determining the normalized mass flow, which is the ratio between the fluid flow and the maximum flow that is obtained when passing water through the filter disk. The normalized mass flow values were plotted as a function of time.

\section{Results and discussion}

\subsection{Characterization of the aphrons fluids}

The aphron fluids were characterized by optical microscopy to visualize the microbubbles. The number, size and size distribution of the microbubbles were determined by using the Size Meter 1.1 program. In general the results showed that the diameter of the aphrons produced with xanthan gum varied from 70 to $164 \mu \mathrm{m}$, while those produced with PHPA had smaller average diameters,

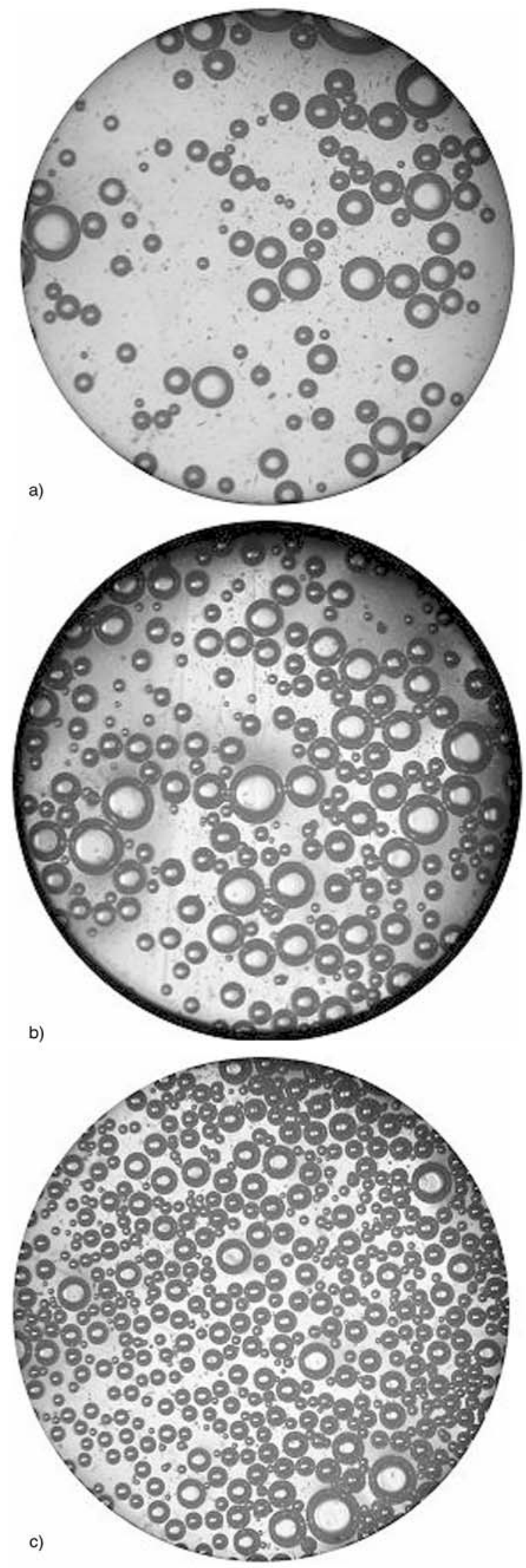

Figure 1. Micrographies of aphrons fluids obtained with xanthan gum at $5.7 \mathrm{~kg} / \mathrm{m}^{3}$, using Blue Streak ${ }^{\circledR}$ surfactant at (a) $2.0 \mathrm{~kg} / \mathrm{m}^{3}$, (b) $4.0 \mathrm{~kg} / \mathrm{m}^{3}$ and (c) $20.0 \mathrm{~kg} / \mathrm{m}^{3}$ 
ranging from 47 to $117 \mu \mathrm{m}$. However, the number of bubbles increased and their size decreased with increasing surfactant concentration, independent of the type of polymer added. Figure 1 shows the micrographs of the fluids containing xanthan gum at a concentration of $11.4 \mathrm{~kg} / \mathrm{m}^{3}$ using Blue Streak ${ }^{\circledR}$ as surfactant.

The correlation between the surfactant concentration and microbubble diameter was better observed in fluids containing low polymer concentration $\left(5.7 \mathrm{~kg} / \mathrm{m}^{3}\right)$, since the system presents lower viscosity.

The number of microbubbles increased with increasing surfactant concentration when using both Blue Streak ${ }^{\circledR}$ and SDS. In the latter case this increase was more pronounced when using xanthan gum as the polymer. With one exception, for PHPAbased fluids, the number of microbubbles declined when the SDS concentration was $20 \mathrm{~kg} / \mathrm{m}^{3}$.

The density of the aphrons produced with xanthan gum declined more rapidly than those prepared with PHPA as the surfactant concentration increased. These results can be related to the volume of incorporated air, because we found that aphrons produced with the anionic surfactants (Blue Streak ${ }^{\circledR}$ and SDS) had similar levels of incorporated air, greater than the level of the aphrons produced with the nonionic surfactant (L10) for fluids containing the two types of polymers. These results are coherent with the density results, i.e., systems prepared with nonionic surfactants are denser.

The viscosity analyses (Figure 2) showed that when xanthan gum was used, the aphron fluids were

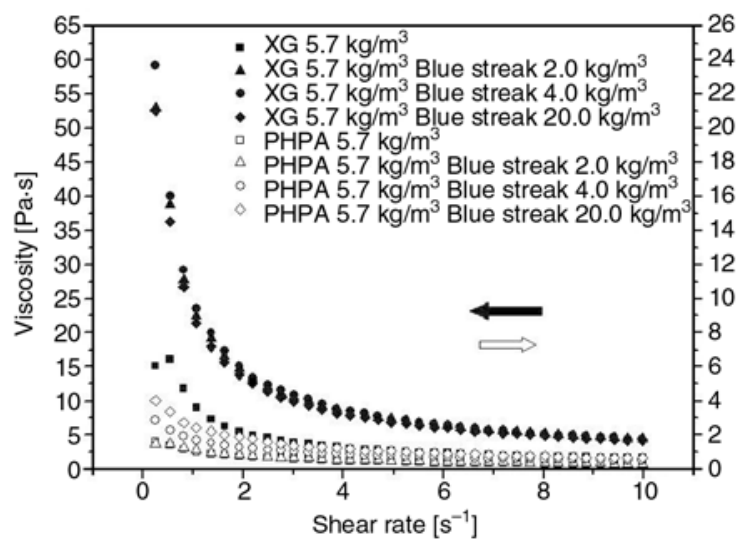

Figure 2. Viscosity against shear rate of base fluids (APX and APP) and aphrons fluids (APX B and APP B) produced with $5.7 \mathrm{~kg} / \mathrm{m}^{3}$ of xanthan gum (APX) or PHPA (APP) and different concentrations of Blue Streak ${ }^{\circledR}\left(2,4\right.$ and $\left.20 \mathrm{~kg} / \mathrm{m}^{3}\right)$ more viscous than their respective base fluids, for all the surfactant concentrations tested. For aphrons fluids produced using PHPA, the viscosity in relation to the base fluid only increased for the highest surfactant concentrations $\left(4.0\right.$ and $20.0 \mathrm{~kg} / \mathrm{m}^{3}$ ). At lower shear rates, there was a slight dependence of the viscosity on the concentration of the surfactant used. The highest viscosity was obtained for the intermediate surfactant concentration. These results suggest there is an optimal surfactant concentration for production of aphrons fluids with controlled viscosities.

\subsection{Evaluation of the base and aphron fluids as filtrate reducers}

We performed tests with the base fluids and aphrons fluids at a pressure of $0.69 \mathrm{MPa}$ (100 psi), using disks with a pore size of $10 \mu \mathrm{m}$. The fluids prepared with xanthan gum at the lowest concentrations (5.7 and $\left.11.4 \mathrm{~kg} / \mathrm{m}^{3}\right)$, using both anionic and nonionic surfactants, did not perform well in reducing filtrate. On the contrary, the presence of microbubbles in these systems caused higher flows through the porous disk in relation to the corresponding base fluid. On the other hand, the aphron fluids with the highest concentration of xanthan gum $\left(22.8 \mathrm{~kg} / \mathrm{m}^{3}\right)$, using both SDS and L10, had structures able to significantly reduce the filtrate flow in relation to the respective base fluid, since this system had a high number of microbubbles with greater average diameter, wider size distribution, lower density and higher volume of incorporated air.

For the PHPA-base fluids, the system with the lowest polymer concentration performed best, due to the fact that its microbubbles had the same characteristics as those produced with a high concentration of xanthan gum. Nevertheless, for the systems formed specifically with L10, increasing the concentration of this surfactant from 2.0 to $4.0 \mathrm{~kg} / \mathrm{m}^{3}$ significantly improved its performance as a filtrate reducer. However, at the highest concentration tested $\left(20.0 \mathrm{~kg} / \mathrm{m}^{3}\right)$, the aphrons had very high normalized mass flow rates, meaning they did not function as a filtrate reducing fluid.

Based on the aphron fluids' characteristics, the average bubble diameter appears to influence their performance. In other words, within the size range of the microbubbles formed, those with a wider size 
Table 1. Percentage of filtrate reduction and characteristics of fluids containing xanthan gum and PHPA, respectively at 22.8 and $5.7 \mathrm{~kg} / \mathrm{m}^{3}$

\begin{tabular}{|c|c|c|c|c|c|c|c|c|}
\hline \multicolumn{3}{|c|}{ Aphrons } & \multicolumn{4}{|c|}{ Characteristics } & \multirow{2}{*}{\multicolumn{2}{|c|}{$\begin{array}{c}\text { Eficiency [\%] } \\
\text { Time [s] }\end{array}$}} \\
\hline \multirow{2}{*}{\multicolumn{2}{|c|}{ Surfactant }} & \multirow{3}{*}{$\begin{array}{c}\text { Conc. } \\
{\left[\mathrm{kg} / \mathrm{m}^{3}\right]}\end{array}$} & \multirow{3}{*}{$\begin{array}{c}\begin{array}{c}\text { Average size } \\
\text { of bubble [ } \boldsymbol{\mu m}]\end{array} \\
- \\
\end{array}$} & \multirow{3}{*}{$\begin{array}{c}\text { Size distribution } \\
\text { of bubbles }[\mu \mathrm{m}]\end{array}$} & \multirow{3}{*}{$\begin{array}{c}\begin{array}{c}\text { Density } \\
{\left[\mathrm{kg} / \mathrm{m}^{3}\right]}\end{array} \\
- \\
\end{array}$} & \multirow{3}{*}{$\begin{array}{c}\begin{array}{c}\text { Air content } \\
{[\%]}\end{array} \\
- \\
\end{array}$} & & \\
\hline & & & & & & & 15 & 60 \\
\hline \multirow{4}{*}{$\begin{array}{l}\stackrel{\Xi}{\Xi} \\
\text { 芯 } \\
\text { 志 } \\
\dot{x}\end{array}$} & - & & & & & & - & - \\
\hline & SDS & 4.0 & 93 & 430 & 590 & 27.6 & 30.6 & 62.0 \\
\hline & SDS & 8.0 & 113 & 390 & 450 & 68.9 & 40.4 & 100.0 \\
\hline & SDS & 20.0 & 77 & 410 & 510 & 50.0 & 42.9 & 58.9 \\
\hline \multirow{5}{*}{$\frac{\mathbb{}}{2}$} & - & - & - & - & - & - & - & - \\
\hline & SDS & 8.0 & 85 & 250 & 780 & 23.3 & (a) & 100.0 \\
\hline & L10 & 2.0 & 81 & 120 & 900 & 10.0 & 0.45 & (a) \\
\hline & L10 & 4.0 & 62 & 160 & 850 & 13.8 & 80.1 & 66.9 \\
\hline & L10 & 20.0 & 51 & 130 & 940 & 7.1 & (a) & (b) \\
\hline
\end{tabular}

(a)The normalized rate of aphrons fluid presented above the rate of their base fluid, that causes the appearing of a negative efficiency (b)In 22 seconds, all aphrons fluid had been passed by the disc

distribution more easily penetrate the pores and consequently perform better at reducing filtrate. The aphrons fluids that performed best were those produced with SDS as the surfactant, independent of the type of polymer used. However, the aphrons fluids produced with PHPA, using L10, were highly efficient in reducing filtrate at the start of the filtration process.

Table 1 shows the efficiency results (filtrate reduction percentage) for the best systems obtained, along with their characteristics. The aphrons fluids produced with L10 and SDS were slightly more efficient. The efficiency results are presented at two times, 15 and 60 seconds. These times are related to the start of the filtrate reduction test and the moment when the normalized flows tended to be constant.

Among these, the aphrons fluids with SDS were most efficient, in shorter analysis times, but in some cases (e.g., the aphrons with $11.4 \mathrm{~kg} / \mathrm{m}^{3}$ of PHPA and $8.0 \mathrm{~kg} / \mathrm{m}^{3}$ of SDS) they completely lost efficiency after 80 seconds, i.e., they attained the same flow rate as the corresponding base fluid.

The best performers among all the aphrons produced were the systems containing $5.7 \mathrm{~kg} / \mathrm{m}^{3}$ of PHPA and $8.0 \mathrm{~kg} / \mathrm{m}^{3}$ of $\mathrm{SDS}$ and containing $22.8 \mathrm{~kg} / \mathrm{m}^{3}$ of xanthan gum and $8.0 \mathrm{~kg} / \mathrm{m}^{3}$ of SDS. The second of these was efficient throughout the filtration process $(15 \mathrm{~s}-40.4 \%$ and $60 \mathrm{~s}-100 \%)$. Thus, it should be tested in larger scale or with core samples from real reservoirs. This system has the advantage of very low density $\left(450 \mathrm{~kg} / \mathrm{m}^{3}\right)$, despite its relatively high polymer and surfactant concentrations $\left(22.8\right.$ and $8.0 \mathrm{~kg} / \mathrm{m}^{3}$, respectively).
The existence of a possible correlation between a system's filtrate reduction performance and the characteristics of the aphrons determined in this study show that the relatively simple methods of evaluating properties utilized in this work for characterizing aphrons fluids can be used to predict their performance. However, the dynamic process of interaction of the fluid with the pores of the rock formation must be taken into consideration. However, this requires evaluation of the dynamic property of the fluid in relation to the pressure variance in the medium through which the bubbles move.

\section{Conclusions}

Both xanthan gum (XG) and partially hydrolyzed polyacrylamide (PHPA) performed well as viscosifiers in the production of aphron fluids. By using xanthan gum it was possible to obtain fluids with higher viscosities than those obtained with PHPA, at the same concentration, since the $\mathrm{XG}$ presents higher thickness performance than PHPA, due to its tendency to form molecular aggregates. In this case, the fluids presented lower densities and incorporated air volumes than that prepared with PHPA. In general, the size of the microbubbles decreased with increasing polymer concentration, probably due to the high viscosity of the fluids, which reduces the diffusion of the microbubbles in the medium. The tests with a ceramic disk with $10 \mu \mathrm{m}$ pore size showed that fluids containing sodium dodecyl sulfate (SDS), at an optimal concentration, performed best in reducing filtrate, independent of the type of polymer used. This can be related to the 
presence of microbubbles with larger average diameters and broader size distribution, besides the low density and high content of incorporated air. Aphrons fluids presenting good performance as filtrate reducer can be obtained by using different formulations, that is, varying kind and concentration of their constituents.

\section{Acknowledgements}

The authors acknowledge the financial support of Petrobras, the Coordinating Office for Improvement of University Researchers (CAPES), the National Council for Scientific and Technological Research $(\mathrm{CNPq})$ and the National Petroleum Agency (ANP). The authors also thank Dow Chemical and Poland Chemical for supplying surfactants and biocide.

\section{References}

[1] Amorim L. V., Farias K. V., Viana J. D., Barbosa M. I. R., Pereira E., França K. B., Lira H. L., Ferreira H. C.: Water based drilling fluids. Part I: Effects of polymeric additives in the rheological properties (in Portuguese). Cerâmica, 51, 128-138 (2005). DOI: $10.1590 / \mathrm{S} 0366-69132005000200010$

[2] Lucas E. F., Mansur C. R. E., Spinelli L. S., Queirós Y. G. C.: Polymer science applied to petroleum production. Pure and Applied Chemistry, 81, 473-494 (2009).

DOI: $\underline{\text { 10.1351/PAC-CON-08-07-21 }}$

[3] Thomas J. E.: Fundamentos da engenharia do petróleo. Editora Interciencia, Rio de Janeiro (2001).

[4] Amorim L. V., Barbosa M. I. R., Ferreira I. H. C.: Bentonite/polymer compound development to application in drilling fluids- Part 2 (in Portuguese). Revista Matéria, 13, 209-219 (2008). DOI: $10.1590 / \mathrm{S} 1517-70762008000100026$

[5] Sadiq R., Husain T., Veitch B., Bose N.: Evaluation of generic types of drilling fluid using a risk-based analytic hierarchy process. Environmental Management, 32, 778-787 (2003) DOI: $\underline{10.1007 / \mathrm{s} 00267-003-0009-2}$
[6] Ivan C. D., Growcock F. B., Friedheim J. E.: Chemical and physical characterization of aphron-based drilling fluids. SPE International, 77445/1-77554/6 (2002). DOI: $\underline{10.2118 / 77445-M S}$

[7] Jauregi P., Gilmour S., Varley J.: Characterisation of colloidal gas aphrons for subsequent use for protein recovery. Chemical Engineering Journal, 65, 1-11 (1997).

DOI: $10.1016 /$ S1385-8947(96)03154-3

[8] Jauregi P., Varley J.: Colloidal gas aphrons: Potential applications in biotechnology. Trends in Biotechnology, 17, 389-395 (1999). DOI: $10.1016 /$ S0167-7799(99)01363-3

[9] Dai Y., Deng T.: Stabilization and characterization of colloidal gas aphron dispersions. Journal of Colloid and Interface Science, 261, 360-365 (2003).

DOI: $\underline{10.1016 / \mathrm{S} 0021-9797(03) 00056-0}$

[10] Mansur E. H. A., Wang Y., Dai Y.: Removal of suspensions of fine particles from water by colloidal gas aphrons (CGA). Separation and Purification Technology, 48, 71-77 (2006).

DOI: 10.1016/j.seppur.2005.07.022

[11] Fuda E., Jauregi P., Pyle D. L.: Recovery of lactoferrin and lactoperoxidase from sweet whey using colloidal gas aphrons (CGAs) generated from an anionic surfactant, AOT. Biotechnology Progress, 20, 514 525 (2004).

DOI: $\underline{10.1021 / \mathrm{bp} 034198 \mathrm{~d}}$

[12] Brookey T., House R.: Aphron-containing well drilling and servicing fluids of enhanced stability. U.S. Patent 6422326, USA (2002).

[13] Spinelli L. S., Neto G. R., Freire L. F. A., Monteiro V., Lomba R., Michel R. C., Lucas E. F.: Synthetic-based aphrons: Correlation between properties and filtrate reduction performance. Colloid and Surface A: Physicochemical and Engineering Aspects, 353, 57-63 (2010).

DOI: $\underline{10.1016 / j . c o l s u r f a .2009 .10 .017}$

[14] Growcoock F. B., Simon G. A., Rea A. B., Leonard R. S., Noello E., Castellan R.: Alternative aphron-based drilling fluid. in 'IADC/SPE Drilling Conference, Dallas, USA', 87134-MS (2004). DOI: $\underline{10.2118 / 87134-M S}$

[15] Growcock F.: Enhanced wellbore stabilization and reservoir productivity with aphron drilling fluid technology. Final Report. MASI Technologies LLC, Houston (2005). 